\title{
Proposed methodology for learning english with the use of TICs. Case: Universidad Tecnológica Equinoccial
}

\author{
Nelson Salgado Reyes ${ }^{1 *}$, Héctor Sanchez Santamaria², Mercedes Rico Garcia ${ }^{2}$
}

\author{
${ }^{1}$ Universidad Tecnológica Equinoccial de Quito, ECUADOR \\ ${ }^{2}$ Universidad de Extremadura, ESPAÑA \\ *Corresponding Author: nelson.salgado@ute.edu.ec
}

\begin{abstract}
Citation: Salgado Reyes, N., Sanchez Santamaria, H., Rico Garcia, M. (2016 Proposed methodology for learning english with the use of TICs.Case: Universidad Tecnológica Equinoccial, Journal of

Information Systems Engineering \& Management, 1:4 (2016), 47.
\end{abstract}

doi: http://dx.doi.org/10.20897/lectito.201647

Received: August 19, 2016; Accepted: September 29, 2016; Published: November 7, 2016

\begin{abstract}
The study presents a proposal for Learning English as a Foreign Language at the "Universidad Tecnológica Equinoccial" (UTE), making use of the Information Technology and based on a previous pedagogical and technological analysis. Internal diagnostics assessed the use of virtual platforms used at UTE and deepened with a diagnostic field research, interviews with some teachers and students, a total of 3072 students and 27 teachers. From the results, a methodological proposal that presents the tools used, components, evaluation, a class structure and practices to be applied to improve Learning English is made. The methodology emphasizes the oral production and listening, through permanent Practices and Activities.
\end{abstract}

Keywords: English learning, methodology, TICs, technological resources, UTE

\section{INTRODUCTION}

The development of communicative competence in English remains an imperative in undergraduate training in contemporary Ecuadorian universities, given the high visibility and presence of this language in the scientific and technical activity and integral cultural development (D. Hymes, 2010), (Romeu, 2011), (Calvo, 2010)..

However, when the current actual status of the teaching and learning of English language in many Ecuadorian universities is reviewed, they can be observed deficiencies for different reasons and variables, which eventually produce a very low level of English in most cases, placing the Ecuador ranked 35th of 63 countries surveyed worldwide (Universo, 2015).

In the research conducted it is based that the lack of methodological work systematized in technological and pedagogical part is one of the causes of insufficient development of professional communicative competence of students in the language and also certain rejection that often show toward same during the process of teaching and learning.

The scientific novelty of this research was the development and systematization of the necessary foundations to support the methodology of learning English at the "Universidad Tecnologica Equinoccial" of Ecuador, with support of information technology. 


\section{THEORETICAL FOUNDATIONS}

The theoretical foundation of teaching in learning languages, different theories, meaningful learning, the relationship with the teacher, the communicative approach, the process of teaching and language learning strategies methodological components, principles the communication skills in English learning, the use of ICT in language learning, teaching through the network and educational platforms (Calvo, 2010), (G. Standley, 2013), (Guillén, 2013). In this theoretical foundation, the fact that learning is a social phenomenon and is related to new technologies actively, being a global phenomenon that drives the ability to speak, act and understand making use of telematics (Bello, 2010), highlights. The Internet-related tools have a lot of information, materials, learning objects and resources that promotes learning (D. Jonassen, 2010). Therefore, the inclusion of ICT in language teaching brings great benefits, using resources such as blogs, wikis, MOOCs, podcasts, virtual environments such as Second Life, among others (G. Standley, 2013). This communication which in some cases takes place in real time by voice chats or written, audio, video, or virtual environments, promotes spontaneous (J. Quinche, 2014) interaction, the immediate response (feedback), motivation, given the authenticity of the environment in favor the participation of more withdrawn students who are not under pressure the classroom. Asynchronous communication by e-mail, online forums, podcasts or video recordings provides advantages such as reflection (E. Field, 2012), critical thinking and social networking learning.

\section{DIAGNOSIS}

To diagnose the current situation of the methodologies used for learning English as a foreign language in the joint venture, platforms currently used in the joint venture were analyzed: (1) the LMS Cambridge, specializing in learning English with international standards software, and (2) complementary tool UTE online platform that serves as virtual support of all subjects offered at the university and therefore used in this case to supplement certain jobs that send teachers to learn English.

It was considered a field study to study the perceptions of students and teachers regarding the methodology and, in general, the teaching-learning process of English in the joint venture.

\section{A. Tools}

3 main tools were used: 1) the survey applied to students and teachers of the UTE, to determine their view on the current methodology used and how they evaluate their learning. 2) Interview, conducted both students and teachers to understand the quality and deeper potential gaps and needs in the teaching-learning process. 3) Finally, an analysis of the platforms used as the methodology applied in the joint venture (Salgado, "Evaluation of methodology and educational practices through the use of virtual platforms for learning English. Case Analysis Language Institute Equinoccial Technological University of Quito.", 2015) university was held.

Thanks to the technological advantages and the existing platform in the joint venture, it has been possible to obtain not only a sample of the results of the survey in relation to the perception of students on the learning of English at the University, with the sample corresponding a total of 3072 of which are 2375 students and 697 classroom No attendance (distance), who replied in full to the survey. On the other hand, teachers and principals are a total of 27 people, which has done the research as a whole, so it is equally a completely reliable result.

\section{B. Critical analysis of the methodology in the UTE}

New theories and especially the practice and experience has shown that the best way to learn English is listening, interacting, talking, writing, and theoretically understanding grammatical structures, but mainly listening and practice allow students to learn so Natural (E. Macaro, 2015). That is why the university currently uses the Cambridge international platform that allows students to develop the interaction and permanent practice; however this tool has some shortcomings, including a lack of interpersonal practice, an aspect that has been considered in the proposal.

\section{Diagnostic Results}

The diagnostic study compiled through surveys and interviews with students and teachers about learning English, shows that about $20 \%$ perceived as fair or poor, expressing satisfaction with low learning outcomes (Figure 1).

Figure 1. Question: How do you consider the methodology for learning English in the joint venture?

According to research students clearly identify what factors could favor learning English, using technological tools in the education program of English in the joint venture are. They have also determined how technological tools in the education program of English in the joint venture are used. Respondents mentioned that the teacher presents his class and uses complementary way the virtual platform and audio as tools, and even less frequently, videos or the Internet are used. 
Upon further research, through surveys and interviews, it was observed that the methodology, as is currently raised, gives teachers the responsibility and control of the classroom, they will be responsible for selecting resources platforms, but with different criteria, ie there is no common methodology for UTE. On the other hand, while learning platforms are accepted by the students, they are also not convinced of its benefits, even though the answers mentioned that information technology can be useful for learning English.

The research developed delves into the factors and technological resources with students, they consider appropriate and those that require strengthening. the contribution that students have different skills in English and delves into the subject through the interview, expanding requesting information and also analyzes the students consider which aspects would improve their learning results were compared with the responses of teachers and finally allowed to draw conclusions from the current situation and some of the foundations for the development of the proposal are.

Different evidence presented in field research and analysis of the methodology and platforms used show the need to improve the methodology in terms of achieving more practical, make use of tools such as videos, conversations and general practices that strengthen learning (Salgado, Evaluation of technological tools for learning English in the joint venture and the perception of students, 2015).

\section{METHODOLOGICAL PROPOSAL FOR THE LEARNING}

\section{ENGLISH Technological University EQUINOCCIAL}

Based on the opinion of teachers and students gained from the research tools used, and considering the theory and analysis, is presented in summary form, the methodology for the teaching and learning of English supported mainly through ICT.

\section{A. Methodology to follow}

The study considered basic aspects to define the methodology: the pedagogical model (teaching methodology), the different components of the program, evaluations and punctuation, structure of classes (and distance), the detail of the aspects to be integrated and activities included.

The proposed methodology hosts several of the parameters of the methodology is currently used in the joint venture, but modifies some aspects for improvement.

The aim of the pedagogical model proposed seeks to provide students with tools for better and more fluent English performance through active and interactive participation in learning.

The methodology aims to promote understanding of language, knowledge, information, vocabulary and grammatical structures through the most natural form of communication is speech.

- The model seeks to enhance the communication capabilities and potential use given in the professional field, as well as everyday life.

- The contents of the methodology are distributed on 8 levels and are based on the Common European Framework (A1-B2)

- The use of the two platforms (UTE online and Cambridge) as the main learning tools, interactive and interpersonal skills to reinforce language practice in complementary practices are maintained.

\section{B. Components of the English program proposed}

English programs through distance or take the same components: 1. Platform Cambridge, 2. Using UTE platform, 3. Written document grammar. 4. Communication to reinforce learning of different skills in Moodle activities.

\section{Class Structure}

Each lesson is supported by learning across platforms mentioned, but include both classroom level and distance, a review and permanent vocabulary practice and interpersonal practices integrated across the following platforms:

1. Lesson through the Cambridge platform (Listening, grammatical structures, and practices)

2. Vocabulary platform Moodle

3. Practice and interpersonal interactive platform Moodle Then each of the points considered in the classes is as follows:

\section{Lessons through the Cambridge Platform}

1) Lessons through the Cambridge Platform

Methodological characteristics of the lessons of the platform

- Independent learning through the learning program.

- Use of ICT for learning advantage audio, video, images and practices.

- Partial evaluations are given by the same platform 
- Learning based on the Common European Framework.

Teacher Support

The teacher in this case becomes a support of the use of the platform (Cambridge), supervising and guiding learning personal level, as each student follows his class independently form the teacher can solve doubts or clarify certain aspects of learning, but in this case, tutoring is personal, when required, allowing greater attention and recruitment, as it is geared to each student and their specific needs.

In the case of distance education due to problems of geographical situation in the country, there are problems of internet in different locations may find additional problems to resolve doubts with agility and speed desired. Using the tool (Cambridge)

The lessons through the platform are autonomous and the only important thing is that the teacher can be a support in some areas reinforcing learning, but without establishing a methodology, which is already established by the LMS.

2) Vocabulary

The vocabulary is critical in learning English, along with the learning and practice grammatical structures proposed in this method, knowledge of an adequate volume of words in English facilitates understanding and communication in English.

Vocabulary practice can be done through access to the Moodle platform. In each level you should consider learning a new group thus generates a progressive acquisition words, focusing on the assimilation of unlearned. The specific number of words in each level will be 150 words in levels (A1A2), 200 words levels (B1-B2), with a total of 1400 keywords learned in a structured way in the process. 3) Interactive and interpersonal Practices

Finally, interactive and interpersonal practices, but are complementary, they represent one of the fundamental aspects in which learning is based from the new methodological proposal, tasks to be performed both remotely and at face level, for which activities will be included UTE raised within the online platform. As an example the following are presented:

Table 1. EXAMPLE OF PROPOSED IN ACTIVE LEARNING PROGRAM

\begin{tabular}{cl}
\hline Practice & \multicolumn{1}{c}{ Explanation of the topic } \\
telephone among students & $\begin{array}{l}\text { a topic will be specified to be treated in which two students engage } \\
\text { in a phone call and conversation in English. } \\
\text { to discuss a topic } \\
\text { specific (Skype) }\end{array}$ \\
The same activity will be done with a program among international \\
students in which calls are from Spanish-speaking students and \\
English speakers to achieve joint objectives (tandem). \\
a central theme of learning, mainly debates that may be related to \\
the topics and vocabularies study be considered. The teacher will \\
moderate and control the participation of all students. \\
No attendance for students will be held at the forum specifically \\
created with a theme defined for this activity. \\
English translation \\
document exchange with students in international convention will \\
be held, where \\
an original text, translation and native speaker student (each of the \\
languages) corrects the text is sent.
\end{tabular}

The study details the required resources and skills strengthened in each of the activities. With this group of examples, it has a number of activities that will be carried out with students, such as group activities, exhibitions, watching movies and series. These activities will be guided by the teacher, but online interaction with speakers, through chat, personal works, which reinforces learning and makes it practical. For distance students, the activity will be included in the joint venture and Moodle platform for development in the corresponding week.

4) Structure for a level classes

Therefore based on the parameters set for learning, class structure for a level, planning should be studied by the area of English and adjusted according to the level presented. 
Table 2. Class structure activities (week 1 to 8 )

1 to 5 days of the week PRACTICAL ACTIVITY

\begin{tabular}{|c|c|c|}
\hline Week & $\begin{array}{c}3 \text { Lessons from the platform } \\
\text { (teaching support) } 1 \text { Review } \\
\text { vocabulary (teaching support) } 1 \\
\text { Class activity practice }\end{array}$ & $\begin{array}{l}\text { Participation in workshops on specific topic of } \\
\text { discussion for students face Participation in } \\
\text { forums created on the platform } \\
\text { Moodle on specific topic, discussion, non- } \\
\text { contact }\end{array}$ \\
\hline Week & $\begin{array}{c}\text { Lessons } \\
\text { platform } \\
1 \text { Review vocabulary }\end{array}$ & $\begin{array}{l}\text { Telephone conversation with students from } \\
\text { other universities connection Skype for the } 2 \\
\text { modalities }\end{array}$ \\
\hline Week & $\begin{array}{c}\text { Lessons } \\
\text { platform } \\
1 \text { Review vocabulary }\end{array}$ & $\begin{array}{l}\text { Exposure groups research topic } \\
\text { Activity: Film in English / Summary }\end{array}$ \\
\hline Week & Writing lesson Exam & Writing lesson Exam \\
\hline
\end{tabular}

\section{CONCLUSIONS}

The proposal presented in this study, consider some changes in methodology and use of technology resources learning English in the joint venture. The changes are based on current tools that owns the UTE, starting from its Cambridge platform, in which internal changes can not be made, but after analyzing its potential, has been considered to increase individual use. On the other hand it has been decided to strengthen the use of the UTE online platform, it can be modified and which can integrate various parts of the proposed method, thereby enhancing the current existing tools.

It presented, the proposal is feasible to perform and is based on various pedagogical, methodological studied in this research as well as analysis of the various theories, learning tools, use of ICT, as well as the perception of teachers and students, which will be possible to give greater support to learning, considering a more natural and practical as it is through speaking, using the various tools currently have the technology learning and the joint venture can access, generating and more motivated, with a constant and active practice, which achieves the same purpose of the proposal is to achieve greater learning English among students of different levels of students UTE. Therefore, based on the results of this research, the University has planned a first pilot application of this methodology for the second semester of the academic test 2015 - 2016.

\section{THANKS}

Special recognition is made to the University Equinoccial technology for its openness to research and delivery of information to make a critical analysis of the current methodology for improving educational quality.

\section{REFERENCES}

Bello, A. (2010). "The voice of liberal learning". Madrid: Katz Editores.

Calvo, M. (2010). "Teaching strategy for the development of intercultural competence in non-English speaking reader preparatory course in Spanish league from the UMCC students." . Matanzas: Doctoral thesis. CEDE / UMCC.

D. Hymes. (2010). "On communicative competence (On Communicative Competence). Elsevier's Editorial House ". Amsterdam.

D. Jonassen, P. K. (2010). "Learning with Technology (Learning with technology)". Upper Saddle River, NJ: Merrill Publishing.

E. Field, \&. E. (2012). "Face to face with discussion forums: the role of time and higher-order thinking". Alcalá: Universidad de Alcalá.

E. Macaro, T. L. (2015). Modern Language in Practice. USA.

G. Standley, L. L. (17 de September de 2013). http://www.teachertube.com. Obtenido de View_video.php: http://www.teachertube.com/view_video.php?viewkey=7097425b52fc7afbb696 (consultation 17-09-2015)

Guillén, G. V. (2013). "Technological Pedagogical Philosophy". Bogota: San Pablo Grupo Editorial. 
J. Quinche, L. G. (2014). "3D Virtual Environments, Educational Alternative for promoting Collaborative Learning and Management Uniminuto knowledge ". Colombia.

Romeu, A. (2011). "The cognitive, communicative and sociocultural approach in teaching language and literature". (Digital format).

Salgado, N. (2015). "Evaluation of methodology and educational practices through the use of virtual platforms for learning English. Case Analysis Language Institute Equinoccial Technological University of Quito.". Vol. 28, no. 5 (2015): CACIED 2015: Second Edition of Andean Congress of Computing, Information and Education, http://www.rte.espol.edu.ec/index.php/tecnologica/search/search.

Salgado, N. (2015). Evaluation of technological tools for learning English in the joint venture and the perception of students. EIDOS Magazine http://www.ute.edu.ec/Revista.aspx?idPortal=15\&idCategoria=1144\&id Section $=1031 \&$ idRevista $=22 \&$ tpo $=1$.

Universo, N. P. (11 de Febrary de 2015). "Ecuador tiene-nivel-bajo-ingles-segun-informe-education-first". www.eluniverso.com, págs. http://www.eluniverso.com/noticias/2015/02/11/nota/4547176/ecuadortiene-nivelbajo-ingles-segun-informe-education-first. (consultation 11-02-2015) 